\title{
The Effect of Sintered $\beta$-Dicalcium Pyrophosphate Particle Size on Newborn Wistar Rat Osteoblasts
}

\author{
*Jui-Sheng Sun, †Yang-Hwei Tsuang, \$Chun-Jen Liao, *Hwa-Chang Liu, \\ *Yi-Shiong Hang, and $\$$ Feng-Huei Lin \\ *Department of Orthopedic Surgery, National Taiwan University Hospital, Taipei; †Department of Orthopedic Surgery, \\ China Medical College Hospital, Taichung; and $\$$ Center of Biomedical Engineering, College of Medicine, National \\ Taiwan University, Taipei, Taiwan, ROC
}

\begin{abstract}
During recent years, sintered dicalcium phosphate (SDCP) has been shown to be an effective artificial bone filler for repairing bone defects. The goal of this study was to elucidate the effect of SDCP particle size on osteoblasts. Osteoblasts were mixed and cultured with various sized SDCP particles (0.5-3.0, 37-63, 177-250, and 420-841 $\mu \mathrm{m}$ ) for $1 \mathrm{~h}, 3 \mathrm{~h}, 1$ day, 3 days, and 7 days and then analyzed. The results show that the adding of smaller sized SDCP particles $(0.5-3.0$ and $37-63 \mu \mathrm{m})$ into osteoblast culture can significantly affect the cell counts of osteoblasts. The secretion of transforming growth factor- $\beta 1$, al-
\end{abstract}

kaline phosphatase, and prostaglandin $\mathrm{E}_{2}$ in culture medium increased significantly. The changes were most significant and persisted longer in smaller particle groups. Small sintered dicalcium phosphate particles can inhibit the proliferation of the osteoblasts. The inhibitory effects of the smaller sized SDCP particles on the osteoblasts were mediated by the promotion of osteoblast differentiation and the increased synthesis of prostaglandin $\mathrm{E}_{2}$. Key Words: Sintered dicalcium phosphate-Particle sizeProstaglandin $\mathrm{E}_{2}$-Transforming growth factor-Osteoblasts.
Bone tissue damage, caused by trauma, tumor, or infection, that creates bone defects must be filled with a suitable substance to accelerate healing or to enable healing. Autografts are preferable because of their superior efficacy and capability of avoiding transmission of infection. However, they do have drawbacks including longer operation and anesthesia times, higher blood loss, donor site morbidity, and limited availability, particularly in children (1). The effectiveness of allogenous bone graft is limited by the problems of the high cost of bone banking, potential of graft-related disease transfer, the high rates of nonunion and infection, and allograft fractures (1). To overcome these problems of natural grafts, research on bone substitute materials has been conducted. However, the biocompatibility and mechanical strength of synthetic materials have limited the success of these artificial biomaterials (2).

\footnotetext{
Received May 1998; revised August 1998.

Address correspondence and reprint requests to Dr. Jui-Sheng Sun, Department of Orthopedic Surgery, National Taiwan University Hospital, College of Medicine, National Taiwan University, No. 7. Chung-Shan South Road, Taipei, Taiwan, ROC. Email: drjssun@ha.mc.ntu.edu.tw
}

With advances in ceramics technology, the application of calcium phosphate materials as bone substitute has recently received considerable attention. They are remarkably biocompatible, provoke little, if any, inflammatory response, and have a bioactive property (3). During the last decade, a large number of biomaterials have been proposed as artificial bone fillers for repairing bone defects. Because of their calcium/phosphate $(\mathrm{Ca} / \mathrm{P})$ ratios, similar to that of natural bone, hydroxyapatite (HA) and tricalcium phosphate (TCP) are the 2 calcium phosphates most commonly used in clinical medicine. HA and other complex calcium phosphate salts are the end products of the biological mineralization process. $\beta$-dicalcium phosphate $(\beta-D C P)$, formula $\mathrm{Ca}_{2} \mathrm{P}_{2} \mathrm{O}_{7}$, is one of the intermediate products in this process (4). The biological response for new bone formation is quite similar between $\beta$-DCP and HA (5). Sintered $\beta-\mathrm{Ca}_{2} \mathrm{P}_{2} \mathrm{O}_{7}$ with $\mathrm{Na}_{4} \mathrm{P}_{2} \mathrm{O}_{7} \cdot 10 \mathrm{H}_{2} \mathrm{O}$ addition (SDCP) was proven to have great potential as an in vivo biodegradable bone substitute $(6,7)$.

The inertness of biomaterials is relative; even materials considered inert in bulk form are capable of eliciting inflammatory reactions in particulate form. 
It has been recognized that particulate debris around an orthopedic implant has an adverse effect on the surrounding tissues. It has been suggested that the adverse effects depend more on the particulate nature of the material than its chemical biocompatibility (8). In our previous study, it was demonstrated that the addition of HA particles into osteoblast culture can significantly affect the behavior of the osteoblasts. The inhibitory effects on the osteoblasts were more significant and persisted longer in smaller particle groups (9). However, there is not yet general understanding as to whether SDCP particles might exert a harmful effect that is similar to but greater than that of their parent material. The goal of our investigation was to study the possible mechanism of various sized SDCP particles on osteoblasts.

\section{MATERIALS AND METHODS}

\section{Material tested}

The powder of sintered $\beta$-dicalcium pyrophosphate (SDCP) with $\mathrm{Na}_{4} \mathrm{P}_{2} \mathrm{O}_{7} \cdot 10 \mathrm{H}_{2} \mathrm{O}$ addition was prepared and briefly described as follows (6). The $\beta$-DCP powder $\left(\beta\right.$-DCP: $\mathrm{Ca}_{2} \mathrm{P}_{2} \mathrm{O}_{7}$, Sigma, St. Louis, MO, U.S.A.) was mixed with 5 wt $\% \mathrm{Na}_{4} \mathrm{P}_{2} \mathrm{O}_{7}$. $10 \mathrm{H}_{2} \mathrm{O}$ in water and dried at $70^{\circ} \mathrm{C}$ for 3 days. The well mixed and dried cake was ground and sieved into 40-60 mesh particles. The sieved particles were placed in a platinum crucible and heated up to $930^{\circ} \mathrm{C}$ at a heating rate of $3^{\circ} \mathrm{C} / \mathrm{min}$ in a conventional Ni-Cr coiled furnace and then maintained in air for $1 \mathrm{~h}$ after the sintering temperature of $930^{\circ} \mathrm{C}$ was reached. The sintered particles were ground and separated with mesh into various grain sizes of about $0.5-3.0,37-63,177-250$, and $420-841 \mu \mathrm{m}$. The SDCP particles were spherical in shape at various grain sizes according to scanning electron microscopic observation. Trace elements that might be connected with biocompatibility were detected by atomic absorption analysis. The concentrations of the trace elements were much lower than the maximum tolerable level. Prior to use, they were processed by dry heat sterilization $\left(130^{\circ} \mathrm{C}, 40 \mathrm{~min}\right)$ as previously reported (9).

\section{Osteoblast-like cell culture}

Sequential digestion of newborn Wistar rat calvaria was performed using a modification of methods previously described (9). Briefly, after pretreatment of the dissected calvaria with $4 \mathrm{mM} \mathrm{Na} \mathrm{Na}_{2}$-EDTA in a prewarmed $\left(37^{\circ} \mathrm{C}\right)$ solution containing $137 \mathrm{mM}$ $\mathrm{NaCl}, 2.7 \mathrm{~m} M \mathrm{KCl}, 3 \mathrm{mM} \mathrm{NaH}{ }_{2} \mathrm{PO}_{4}$, pH 7.2 (Solution A), for 10 min 3 times, the fragments were sequential digested with collagenase (180 U/ml, Sigma) in Solution A with EDTA. The sequential digestion consisted of 4 time treatments for 5 min followed by two time treatments for $10 \mathrm{~min}$. The cells released after each treatment were immediately harvested by centrifugation and resuspended in culture medium. The osteoblastic phenotype of the cells was assessed by the tests of alkaline phosphatase assay.

\section{Experimental procedures}

In the experiment, confluent rat osteoblast cultures were passaged by trypsin-EDTA and then seeded into six $3.0 \times 3.0 \mathrm{~mm}$ tissue culture wells (seeding density of $1 \times 10^{5}$ cells/well). The culture medium used was Dulbecco's modified Eagle's medium supplemented with $10 \%$ fetal calf serum (Gibco BRL, Grand Island, NY, U.S.A.), penicillin G sodium $100 \mathrm{U} / \mathrm{ml}$, and streptomycin $100 \mathrm{mg} / \mathrm{ml}$ (Gibco BRL, Grand Island, NY, U.S.A.). The dishes were incubated at $37^{\circ} \mathrm{C}$ in an atmosphere supplemented with $5 \% \mathrm{CO}_{2}$ for $24 \mathrm{~h}$ to facilitate the attachment of osteoblasts. The medium was then removed and washed twice with PBS solution. Dulbecco's modified Eagle's medium supplemented with ITS (Insulin, $10 \mu \mathrm{g} / \mathrm{ml}$ medium; transferrin, 5 $\mu \mathrm{g} / \mathrm{ml}$ medium; and sodium selenite, $5 \times 10^{-3} \mu \mathrm{g} / \mathrm{ml}$ medium Sigma) was mixed with $0.1 \%(1 \mathrm{mg} / \mathrm{ml})$ of various sized SDCP particles. The day of plating was considered as the zero day of culture. The test media were removed from wells at 1 and $3 \mathrm{~h}$ and Days 1, 3 , and 7; divided into $500 \mu \mathrm{l}$ sections with eppendorf; and deep frozen in $-80^{\circ} \mathrm{C}$ till further analysis.

\section{Cell count}

After removal of the medium, the wells were fixed with $3 \%$ formaldehyde in $0.1 M$ phosphate buffered saline (PBS) buffer ( $\mathrm{pH}$ 7.4). The samples were stained with hematoxylin-eosin and then observed by inverted microscopy (Olympus, IMT-II, Shibuyaku, Tokyo, Japan). The cellularities of the control and experimental wells were determined by an MICD image analyzing system (MICD Software Series, Image Research, Inc., Ontario, Canada). Briefly, the mean cell populations in 4 randomly selected high power fields $\left(0.06 \mathrm{~mm}^{2}\right)$ were measured by counting the number of nuclei caught by a CCD72 camera (Dage-MII, Inc., Michigan City, IN, U.S.A.) through the microscope. Then the cell count per well was calculated by multiplying the area of each well $\left(940 \mathrm{~mm}^{2} /\right.$ well $)$.

\section{Analysis of transforming growth factor- $\beta 1$ in culture medium}

The production of transforming growth factor$\beta 1$ (TGF- $\beta 1$ ) in culture medium was analyzed by ELISA methods. Briefly, $200 \mu l$ of standard or sample was added per well. The tested samples were 
incubated for $3 \mathrm{~h}$ at room temperature on the benchtop. Then $200 \mu$ l of TGF- $\beta 1$ (R \& D System, Inc., Minneapolis, MN, U.S.A.) conjugate was added, and the samples were incubated for $1.5 \mathrm{~h}$ at room temperature. Two hundred milliliters of substrate solution was added to each well. The reaction was stopped and read by Microelisa reader (Emax Science, Sunnyvale, CA, U.S.A.) at $450 \mathrm{~nm}$ after $20 \mathrm{~min}$ of incubation.

\section{Analysis of alkaline phosphatase in culture medium}

Alkaline phosphatase (ALP) activity released from the cells into the medium was measured with a commercially available assay kit (Procedure No. ALP-10, Sigma, St. Louis, MO, U.S.A.). Briefly, an aliquot $(20 \mu \mathrm{l})$ from the medium was mixed with 1 $\mathrm{ml}$ alkaline phosphatase reagent. The absorbance at $405 \mathrm{~nm}$ caused by p-nitrophenol production was followed for $5 \mathrm{~min}$ at $30^{\circ} \mathrm{C}$. The change in rate of absorbance was found to be directly proportional to alkaline phosphatase activity.

\section{Analysis of prostaglandin $E_{\mathbf{2}}$ in culture medium}

The production of prostaglandin $\mathrm{E}_{2}\left(\mathrm{PGE}_{2}\right)$ in culture medium was also analyzed by ELISA methods. Briefly, $50 \mu \mathrm{l}$ of standard $\mathrm{PGE}_{2}$ (Cayman Chemical Company, Ann Arbor, MI, U.S.A.) or sample was added per well. The tested samples were incubated for $18 \mathrm{~h}$ at room temperature on the benchtop. Then $200 \mu \mathrm{l}$ of Ellman's reagent was added to each well, and the samples incubated for $1.5 \mathrm{~h}$ at room tem- perature. The reaction was stopped and read by a Microelisa reader (Emax Science, Sunnyvale, CA, U.S.A.) at $405 \mathrm{~nm}$. The synthesis of $\mathrm{PGE}_{2}$ by osteoblasts was measured by multiplying the concentration of $\mathrm{PGE}_{2}$ with the volume of the medium and then dividing by the calculated cell population at various tested periods.

\section{Statistical analysis}

The differences between various sized SDCP particles were evaluated by the analysis of variance statistics method. The post hoc test performed was Bonferroni's $t$-test. The level of statistical significance was defined as $\mathrm{p}<0.05$.

\section{RESULTS}

\section{Cell count}

The adding of SDCP particles into osteoblast culture can significantly affect the cell counts of osteoblasts. The cell populations of the control and the samples cultured with various sized SDCP particles are summarized in Table 1 . The changes of cell population of various preparations at $1 \mathrm{~h}, 3 \mathrm{~h}, 1$ day, 3 days, and 7 days were all statistically significant ( $\mathrm{p}$ $<0.0001$ by ANOVA test) (Table 1 ).

The changes in cell population were quite similar between the control and the groups with larger particle sized SDCP (i.e., 177-250 $\mu \mathrm{m}$ and $420-841 \mu \mathrm{m}$ ). They increased in the first 3 day culture and then reached a plateau at the 7 day culture. When cultured with SDCP with smaller particle sizes (i.e., 0.5$3.0 \mu \mathrm{m}$ and $37-83 \mu \mathrm{m})$, the osteoblast populations

TABLE 1. Changes of cell population for osteoblasts cultured with various sized synthetic SDCP bioceramics

\begin{tabular}{|c|c|c|c|c|c|}
\hline \multirow{2}{*}{$\begin{array}{c}\text { Group } \\
\text { (particle size) }\end{array}$} & \multicolumn{5}{|c|}{ Cell count $\left(\times 10^{4} /\right.$ well $)$} \\
\hline & $1 \mathrm{~h}^{a}$ & $3 \mathrm{~h}^{b}$ & 1 day $^{c}$ & 3 days $^{d}$ & 7 days $^{e}$ \\
\hline $\mathrm{A}_{(0.5-3.0 \mu \mathrm{m})}$ & $\begin{array}{l}25.39^{f} \\
(\mathrm{SD} 8.06)\end{array}$ & $\begin{array}{c}34.82^{f} \\
(\mathrm{SD} 12.35)\end{array}$ & $\begin{array}{c}16.90^{g} \\
(\mathrm{SD} 4.23)\end{array}$ & $\begin{array}{c}15.37^{g} \\
(\mathrm{SD} 8.76)\end{array}$ & $\begin{array}{c}20.81^{g} \\
(\mathrm{SD} 10.72)\end{array}$ \\
\hline B $(37-63 \mu \mathrm{m})$ & $\begin{array}{l}26.53^{f} \\
(\mathrm{SD} 8.93)\end{array}$ & $\begin{array}{l}31.14^{f} \\
(\mathrm{SD} 14.43)\end{array}$ & $\begin{array}{c}16.39^{g} \\
(\mathrm{SD} 4.26)\end{array}$ & $\begin{array}{c}33.30^{g} \\
(\mathrm{SD} 14.55)\end{array}$ & $\begin{array}{c}28.87^{g} \\
(\mathrm{SD} 15.26)\end{array}$ \\
\hline $\mathrm{C}_{(177-250 \mu \mathrm{m})}$ & $\begin{array}{c}35.84 \\
(\mathrm{SD} 14.90)\end{array}$ & $\begin{array}{c}44.56 \\
(\mathrm{SD} 13.93)\end{array}$ & $\begin{array}{c}55.32 \\
(\mathrm{SD} 16.27)\end{array}$ & $\begin{array}{c}137.92 \\
(\mathrm{SD} 19.71)\end{array}$ & $\begin{array}{c}130.21 \\
(\mathrm{SD} 19.22)\end{array}$ \\
\hline D $(420-841 \mu \mathrm{m})$ & $\begin{array}{l}39.48 \\
(\mathrm{SD} 15.54)\end{array}$ & $\begin{array}{c}49.81 \\
(\mathrm{SD} 17.95)\end{array}$ & $\begin{array}{c}57.59 \\
(\mathrm{SD} 20.71)\end{array}$ & $\begin{array}{c}146.68 \\
(\mathrm{SD} 27.57)\end{array}$ & $\begin{array}{c}142.77 \\
(\mathrm{SD} 46.33)\end{array}$ \\
\hline E Control & $\begin{array}{c}44.05 \\
(\mathrm{SD} 19.84)\end{array}$ & $\begin{array}{c}47.46 \\
(\mathrm{SD} 13.31)\end{array}$ & $\begin{array}{c}47.26 \\
\text { (SD 16.60) }\end{array}$ & $\begin{array}{c}147.03 \\
(\mathrm{SD} 24.88)\end{array}$ & $\begin{array}{c}140.62 \\
(\mathrm{SD} 49.06)\end{array}$ \\
\hline $\mathrm{p}$ value & 0.0188 & 0.0229 & $7.86 \times 10^{-10}$ & $3.01 \times 10^{-22}$ & $8.19 \times 10^{-12}$ \\
\hline
\end{tabular}

${ }^{a} \mathrm{p}<0.05$ between Groups A and B and Groups C, D, and E.

${ }^{b} \mathrm{p}<0.05$ between Groups A, B and Groups C, D, E.

${ }^{c} \mathrm{p}<0.0005$ between Groups A, B and Groups C, D, E.

${ }^{d} \mathrm{p}<0.0005$ between Groups A, B and Groups C, D, E; $0.005<\mathrm{p}<0.05$ between Groups A and $\mathrm{B}$.

${ }^{e} \mathrm{p}<0.0005$ between Groups A, B and Groups C, D, E.

${ }^{f} \mathrm{p}<0.05$ when compared to control group.

${ }^{g} \mathrm{p}<0.0005$ when compared with control group.

SDCP concentration, $1 \mathrm{mg} / \mathrm{ml}(\mathrm{n}=10)$.

All data were analyzed by ANOVA test. SD: standard deviation. 
were significantly lower than that of the control $(\mathrm{p}<$ 0.05 ) (Table 1). The cell population of the smaller sized SDCP was less.

\section{Transforming growth factor- $\beta 1$ in culture medium}

The TGF- $\beta 1$ concentrations in the culture medium were not significantly affected while the changes in the secretion of TGF- $\beta 1$ by osteoblastlike cells were significantly affected by the addition of SDCP particles especially when the particles were smaller in size (Table 2).

The secretion of TGF- $\beta 1$ by osteoblast-like cells in medium at $1 \mathrm{~h}$ was low and not statistically significant ( $\mathrm{p}=0.4298)$. The changes at $3 \mathrm{~h}, 1$ day, 3 days, and 7 days were statistically significant $(\mathrm{p}<0.05$ by ANOVA test) (Table 2).

The secretions of TGF- $\beta 1$ by osteoblast-like cells in the control medium tested were quite similar to those of the experimental medium with SDCP sizes $177-250 \mu \mathrm{m}$ and $420-841 \mu \mathrm{m}(\mathrm{p}>0.05)$. The TGF- $\beta 1$ secretions by osteoblast-like cells in the culture medium of the smaller sized SDCP $(0.5-3.0 \mu \mathrm{m}$ and $37-63 \mu \mathrm{m})$ were always significantly higher than that of the control medium after $3 \mathrm{~h}$ of implantation and persisted until the 7 day culture (Table 2). The increases of TGF- $\beta 1$ secretion in the culture medium were most significant in the groups with the smallest particles (i.e., 0.5-3.0 $\mu \mathrm{m}$ SDCP).

\section{Alkaline phosphatase in culture medium}

The concentrations of ALP in the culture medium and the secretion of ALP by osteoblast-like cells of various preparations are shown in Table 3. There were no statistically significant changes in the ALP concentrations of various sized SDCP particles while the changes in the ALP secretion of various sized SDCP particles were all statistically significant except the $1 \mathrm{~h}$ culture $(\mathrm{p}=0.08578)$ (Table 3$)$.

The secretion of ALP by osteoblast-like cells in the control medium tested were quite similar to those of the medium with SDCP sized 177-250 $\mu \mathrm{m}$ and $420-841 \mu \mathrm{m}(\mathrm{p}>0.05)$, and it decreased gradually until the end of the 7th day's culture. The ALP secretions by osteoblast-like cells in the culture medium with smaller sized SDCP $(0.5-3.0 \mu \mathrm{m}$ and 37$63 \mu \mathrm{m})$ were always significantly greater than that of the control after $3 \mathrm{~h}$ implantation and persisted until the 7 day culture (Table 3 ). Similar to the changes of TGF- $\beta 1$ secretion, increases of ALP secretion in the culture medium were most significant in the groups with the smallest particles (i.e., 0.5-3.0 $\mu \mathrm{m}$ SDCP).

\section{Prostaglandin $\mathbf{E}_{\mathbf{2}}$ in culture medium}

The concentrations of $\mathrm{PGE}_{2}$ in the culture medium and the secretion of $\mathrm{PGE}_{2}$ by osteoblast-like cells of the various preparations are shown in Table 4. The concentration of $\mathrm{PGE}_{2}$ in the culture medium increased significantly immediately after adding SDCP particles, and the changes were most significant in medium with the smallest SDCP particles (Table 4).

The changes of $\mathrm{PGE}_{2}$ secretion by osteoblast-like cells were also statistically significant $(\mathrm{p}<0.005$ by ANOVA test). The $\mathrm{PGE}_{2}$ secretion by osteoblastlike cells increased in the initial $3 \mathrm{~h}$, then rapidly decreased after the 1 day culture (Table 4). The

TABLE 2. Changes of TGF- $\beta 1$ concentration in culture medium and TGF- $\beta 1$ secretion when osteoblasts were cultured with various sized synthetic (SDCP) bioceramics

\begin{tabular}{|c|c|c|c|c|c|c|c|c|c|c|}
\hline \multirow{2}{*}{$\begin{array}{c}\text { Group } \\
\text { (particle size) }\end{array}$} & \multicolumn{5}{|c|}{ TGF- $\beta 1$ concentration $(\mathrm{pg} / \mathrm{ml})$} & \multicolumn{5}{|c|}{ TGF- $\beta 1$ secretion ( $\mathrm{pg} / 10^{4}$ cells) } \\
\hline & $1 \mathrm{~h}$ & $3 \mathrm{~h}$ & 1 day & 3 days & 7 days & $1 \mathrm{~h}$ & $3 \mathrm{~h}^{a}$ & 1 day $^{b}$ & 3 days $^{c}$ & 7 days $^{d}$ \\
\hline A $(0.5-3.0 \mu \mathrm{m})$ & $\begin{array}{c}12.65 \\
\text { (SD 11.67) }\end{array}$ & $\begin{array}{c}11.69^{f} \\
(\mathrm{SD} 0.93)\end{array}$ & $\begin{array}{c}69.84^{f} \\
(\mathrm{SD} 25.62)\end{array}$ & $\begin{array}{l}216.36 \\
\text { (SD 19.51) }\end{array}$ & $\begin{array}{l}193.96 \\
\text { (SD 45.90) }\end{array}$ & $\begin{array}{c}1.19 \\
\text { (SD 1.09) }\end{array}$ & $\begin{array}{l}1.12^{g} \\
\text { (SD } 0.40)\end{array}$ & $\begin{array}{l}13.43^{g} \\
\text { (SD 6.43) }\end{array}$ & $\begin{array}{c}49.92^{h} \\
(\mathrm{SD} 20.08)\end{array}$ & $\begin{array}{l}88.18^{g} \\
\text { (SD 44.20) }\end{array}$ \\
\hline B $(37-63 \mu \mathrm{m})$ & $\begin{array}{l}9.63 \\
\text { (SD } 9.32)\end{array}$ & $\begin{array}{l}14.04^{g} \\
\text { (SD } 6.22)\end{array}$ & $\begin{array}{c}69.67^{f} \\
\text { (SD 18.04) }\end{array}$ & $\begin{array}{l}209.28 \\
\text { (SD 18.57) }\end{array}$ & $\begin{array}{l}184.89 \\
\text { (SD 48.88) }\end{array}$ & $\begin{array}{l}1.34 \\
\text { (SD 1.05) }\end{array}$ & $\begin{array}{l}1.59^{g} \\
\text { (SD 1.16) }\end{array}$ & $\begin{array}{l}13.62^{g} \\
\text { (SD 3.86) }\end{array}$ & $\begin{array}{c}25.09^{g} \\
(\mathrm{SD} 18.50)\end{array}$ & $\begin{array}{l}60.26^{g} \\
\text { (SD 28.23) }\end{array}$ \\
\hline $\mathrm{C}_{(177-250 \mu \mathrm{m})}$ & $\begin{array}{l}11.56 \\
\text { (SD 5.51) }\end{array}$ & $\begin{array}{c}8.60 \\
(\mathrm{SD} 7.17)\end{array}$ & $\begin{array}{l}72.32^{f} \\
(\mathrm{SD} \mathrm{13.24)}\end{array}$ & $\begin{array}{l}227.60 \\
\text { (SD 31.39) }\end{array}$ & $\begin{array}{l}214.56 \\
\text { (SD } 40.45 \text { ) }\end{array}$ & $\begin{array}{l}1.26 \\
\text { (SD 0.99) }\end{array}$ & $\begin{array}{l}0.64 \\
\text { (SD 0.42) }\end{array}$ & $\begin{array}{l}4.52 \\
\text { (SD 2.72) }\end{array}$ & $\begin{array}{c}5.02^{f} \\
(\mathrm{SD} 1.02)\end{array}$ & $\begin{array}{l}5.16 \\
\text { (SD 1.07) }\end{array}$ \\
\hline D & $\begin{array}{l}12.57 \\
\text { (SD 7.11) }\end{array}$ & $\begin{array}{l}14.96^{g} \\
\text { (SD } 4.72)\end{array}$ & $\begin{array}{c}69.85^{f} \\
(\mathrm{SD} 14.47)\end{array}$ & $\begin{array}{l}222.45 \\
\text { (SD 35.70) }\end{array}$ & $\begin{array}{l}230.90 \\
\text { (SD 41.19) }\end{array}$ & $\begin{array}{l}1.03 \\
(\mathrm{SD} 0.74)\end{array}$ & $\begin{array}{l}0.67 \\
\text { (SD } 0.31)\end{array}$ & $\begin{array}{l}4.11 \\
(\mathrm{SD} 1.61)\end{array}$ & $\begin{array}{c}4.66^{f} \\
(\mathrm{SD} 0.94)\end{array}$ & $\begin{array}{l}5.37 \\
\text { (SD 2.42) }\end{array}$ \\
\hline E Control & $\begin{array}{c}8.60 \\
(\mathrm{SD} 7.00)\end{array}$ & $\begin{array}{c}8.48 \\
\text { (SD 5.13) }\end{array}$ & $\begin{array}{l}90.25 \\
\text { (SD 13.15) }\end{array}$ & $\begin{array}{l}231.74 \\
(\mathrm{SD} 28.68)\end{array}$ & $\begin{array}{l}233.91 \\
\text { (SD 50.64) }\end{array}$ & $\begin{array}{c}0.74 \\
(\mathrm{SD} 0.49)\end{array}$ & $\begin{array}{l}0.54 \\
\text { (SD 0.31) }\end{array}$ & $\begin{array}{l}9.13 \\
\text { (SD 6.04) }\end{array}$ & $\begin{array}{c}4.02 \\
(\mathrm{SD} 0.70)\end{array}$ & $\begin{array}{l}5.56 \\
\text { (SD 2.13) }\end{array}$ \\
\hline $\mathrm{p}$ value & 0.6926 & 0.0127 & 0.0344 & 0.3056 & 0.0764 & 0.4298 & 0.0033593 & 0.002014 & $1.95 \times 10^{-11}$ & 0.000178 \\
\hline
\end{tabular}

${ }^{a}$ No significant difference among all measurements.

${ }^{b} \mathrm{p}<0.005$ between Groups A, B and Groups C, D, E.

${ }^{c} \mathrm{p}<0.005$ between Groups A, B and Groups C, D, E.

$d_{\mathrm{p}}<0.0005$ between Group A and Group B; $\mathrm{p}<0.005$ between Groups A, B and Groups C, D, E; p $<0.05$ between Groups C, D and Group E; p $>0.05$

between Group C and Group D.

${ }_{f}^{e} \mathrm{p}<0.005$ between Groups A, B and Groups C, D, E.

${ }^{f} \mathrm{p}<0.05$ compared to control group.

${ }^{g} \mathrm{p}<0.005$ compared to control group.

${ }^{h} \mathrm{p}<0.0005$ compared to control group.

SDCP concentration, $1 \mathrm{mg} / \mathrm{ml}(\mathrm{n}=10)$.

All data were analyzed by ANOVA test. SD: standard deviation. 
TABLE 3. Changes of alkaline phosphatase $(A L P)$ concentration in culture medium and secretion of ALP when osteoblasts were cultured with various sized SDCP bioceramics

\begin{tabular}{|c|c|c|c|c|c|c|c|c|c|c|}
\hline \multirow{2}{*}{$\begin{array}{c}\text { Group } \\
\text { (particle size) }\end{array}$} & \multicolumn{5}{|c|}{ ALP concentration $(\mathrm{U} / \mathrm{ml})$} & \multicolumn{5}{|c|}{ ALP secretion (U/10 $0^{4}$ cells) } \\
\hline & $1 \mathrm{~h}$ & $3 \mathrm{~h}$ & 1 day & 3 days & 7 days & $1 \mathrm{~h}^{a}$ & $3 \mathrm{~h}^{b}$ & 1 day $^{c}$ & 3 days $^{d}$ & 7 days $^{e}$ \\
\hline $\begin{array}{l}\text { A } \\
(0.5-3.0 \mu \mathrm{m})\end{array}$ & $\begin{array}{c}42.01 \\
\text { (SD 4.28) }\end{array}$ & $\begin{array}{c}46.16 \\
\text { (SD 6.12) }\end{array}$ & $\begin{array}{l}46.16 \\
\text { (SD 7.14) }\end{array}$ & $\begin{array}{c}45.88 \\
(\mathrm{SD} 4.55)\end{array}$ & $\begin{array}{l}39.53 \\
\text { (SD 5.98) }\end{array}$ & $\begin{array}{l}4.09 \\
\text { (SD 2.37) }\end{array}$ & $\begin{array}{l}3.68^{g} \\
\text { (SD 1.37) }\end{array}$ & $\begin{array}{c}7.50^{g} \\
(\mathrm{SD} 3.15)\end{array}$ & $\begin{array}{c}8.71^{h} \\
(\mathrm{SD} 3.30)\end{array}$ & $\begin{array}{c}16.67^{g} \\
(\mathrm{SD} 8.14)\end{array}$ \\
\hline $\mathrm{B}$ & 38.14 & 40.63 & 40.91 & 38.42 & 36.49 & 4.03 & $3.63^{g}$ & $6.74^{g}$ & $3.91^{g}$ & $10.97^{g}$ \\
\hline$(37-63 \mu \mathrm{m})$ & (SD 6.99) & (SD 5.98) & $(\mathrm{SD} 7.80)$ & $(\mathrm{SD} 8.59)$ & (SD 8.82) & (SD 1.54) & (SD 1.09) & (SD 2.46) & $(\mathrm{SD} 1.49)$ & (SD 5.08) \\
\hline $\mathrm{C}$ & 37.04 & 39.25 & 41.18 & 36.21 & 35.66 & 3.24 & 2.41 & 2.12 & 0.66 & 0.73 \\
\hline$(177-250 \mu \mathrm{m})$ & (SD 7.51) & $(\mathrm{SD} 8.01)$ & (SD 4.21) & (SD 6.17) & (SD 6.17) & (SD 1.99) & (SD 0.90) & (SD 1.13) & $(\mathrm{SD} 0.10)$ & $(\mathrm{SD} 0.23)$ \\
\hline$(420-841 \mu \mathrm{m})$ & (SD 6.92) & $(\mathrm{SD} 7.71)$ & $(\mathrm{SD} 8.08)$ & (SD 11.24) & $(\mathrm{SD} 7.95)$ & (SD 1.07) & $(\mathrm{SD} 0.70)$ & (SD 0.63) & $(\mathrm{SD} 0.16)$ & $(\mathrm{SD} 0.28)$ \\
\hline $\mathrm{E}$ & 40.35 & 36.49 & 40.35 & 37.59 & 38.14 & 2.82 & 2.05 & 3.08 & 0.65 & 0.75 \\
\hline Control & (SD 6.80) & (SD 8.22) & (SD 7.84) & (SD 4.91) & (SD 6.87) & (SD 1.57) & (SD 0.70) & (SD 1.62) & $(\mathrm{SD} 0.10)$ & (SD 0.27) \\
\hline $\mathrm{p}$ value & 0.364 & 0.0687 & 0.1894 & 0.0533 & 0.7883 & 0.08578 & 0.0002948 & $7.17 \times 10^{-7}$ & $1.73 \times 10^{-12}$ & $9.77 \times 10^{-5}$ \\
\hline
\end{tabular}

${ }^{a} \mathrm{p}>0.05$ between all measurements.

${ }^{b} \mathrm{p}<0.005$ between Groups A, B and Groups C, D, E.

${ }^{c} \mathrm{p}<0.005$ between Groups A, B and Groups C, D, E.

${ }^{d} \mathrm{p}<0.005$ between Groups A, B and Groups C, D, E; p $<0.005$ between Group A and Group B.

${ }^{e} \mathrm{p}<0.005$ between Groups A, B and Groups C, D, E.

${ }^{f} \mathrm{p}<0.05$ compared to control group.

${ }^{g} \mathrm{p}<0.005$ compared to control group.

${ }^{h} \mathrm{p}<0.0005$ compared to control group.

$\mathrm{SDCP}$ concentration, $1 \mathrm{mg} / \mathrm{ml}(\mathrm{n}=10)$.

All data were analyzed by ANOVA test. SD: standard deviation.

changes in $\mathrm{PGE}_{2}$ secretion by osteoblast-like cells tested with particle sizes $177-250 \mu \mathrm{m}$ and $420-841$ $\mu \mathrm{m}$ were quite similar to that of the control medium but at a little higher level (Table 4). The changes in $\mathrm{PGE}_{2}$ secretion by osteoblast-like cells tested with smaller particle sizes $(37-63 \mu \mathrm{m}$ and $0.5-3.0 \mu \mathrm{m})$ were quite obvious and always higher than those of the other 3 groups (Table 4). The changes in $\mathrm{PGE}_{2}$ secretion by osteoblast-like cells corresponded to the changes of cell population, TGF- $\beta 1$, and ALP secretion when osteoblasts were cultured with various sized SDCP particles (Fig. 1).

\section{DISCUSSION}

During the last decade, a large number of biomaterials have been proposed as artificial bone fillers for repairing bone defects. The materials most widely used in clinical medicine have been HA ceramics (3). However, the use of block forms of porous HA has resulted in an unacceptably high failure rate in clinical applications (10). We have investigated the size effect of HA particles on the osteoblasts. We found that the addition of HA particles into osteoblast cultures can significantly affect the

TABLE 4. Changes of prostaglandin- $E_{2}\left(P G E_{2}\right)$ concentration in culture medium and secretion of PGE $E_{2}$ when osteoblasts were cultured with various sized SDCP bioceramics

\begin{tabular}{|c|c|c|c|c|c|c|c|c|c|c|}
\hline \multirow{2}{*}{$\begin{array}{c}\text { Group } \\
\text { (particle size) }\end{array}$} & \multicolumn{5}{|c|}{$\mathrm{PGE}_{2}$ concentration $(\mathrm{pg} / \mathrm{ml})$} & \multicolumn{5}{|c|}{$\mathrm{PGE}_{2}$ secretion $\left(\mathrm{pg} / 10^{4}\right.$ cells $)$} \\
\hline & $1 \mathrm{~h}$ & $3 \mathrm{~h}$ & 1 day & 3 days & 7 days & $1 \mathrm{~h}^{d}$ & $3 \mathrm{~h}^{e}$ & 1 day $^{f}$ & 3 days $^{g}$ & 7 days $^{h}$ \\
\hline A $(0.5-3.0 \mu \mathrm{m})$ & $\begin{array}{l}282.83^{a} \\
(\mathrm{SD} 111.72)\end{array}$ & $\begin{array}{l}278.52^{b} \\
(\mathrm{SD} 93.92)\end{array}$ & $\begin{array}{c}202.07 \\
(\mathrm{SD} 105.14)\end{array}$ & $\begin{array}{c}240.19^{b} \\
(\mathrm{SD} 127.73)\end{array}$ & $\begin{array}{c}242.6^{a} \\
(\mathrm{SD} 80.44)\end{array}$ & $\begin{array}{l}33.93^{a} \\
(\mathrm{SD} 8.22)\end{array}$ & $\begin{array}{l}26.19^{b} \\
(\mathrm{SD} 10.93)\end{array}$ & $\begin{array}{l}32.92^{a} \\
(\mathrm{SD} 19.56)\end{array}$ & $\begin{array}{l}41.43^{a} \\
(\mathrm{SD} 20.83)\end{array}$ & $\begin{array}{l}112.91^{c} \\
(\mathrm{SD} 55.76)\end{array}$ \\
\hline B $(37-63 \mu \mathrm{m})$ & $\begin{array}{l}242.15^{b} \\
(\mathrm{SD} 88.20)\end{array}$ & $\begin{array}{l}204.12 \\
(\mathrm{SD} 72.95)\end{array}$ & $\begin{array}{l}213.16 \\
\text { (SD 135.93) }\end{array}$ & $\begin{array}{l}171.36 \\
\text { (SD 79.92) }\end{array}$ & $\begin{array}{c}260.81^{c} \\
(\mathrm{SD} 85.90)\end{array}$ & $\begin{array}{c}28.78^{a} \\
(\mathrm{SD} 10.81)\end{array}$ & $\begin{array}{l}22.71^{b} \\
(\operatorname{SD} 9.22)\end{array}$ & $\begin{array}{l}38.96^{a} \\
\text { (SD 21.37) }\end{array}$ & $\begin{array}{l}16.45^{a} \\
\text { (SD 7.38) }\end{array}$ & $\begin{array}{l}104.04^{c} \\
(\mathrm{SD} 52.36)\end{array}$ \\
\hline C $(177-250 \mu \mathrm{m})$ & $\begin{array}{l}145.31 \\
(\mathrm{SD} 81.03)\end{array}$ & $\begin{array}{l}163.70 \\
(\mathrm{SD} 64.26)\end{array}$ & $\begin{array}{c}171.82 \\
(\mathrm{SD} 139.16)\end{array}$ & $\begin{array}{l}117.20 \\
\text { (SD 82.36) }\end{array}$ & $\begin{array}{c}124.66 \\
(\mathrm{SD} 39.60)\end{array}$ & $\begin{array}{c}13.10 \\
(\mathrm{SD} 8.27)\end{array}$ & $\begin{array}{l}13.83 \\
(\mathrm{SD} 8.26)\end{array}$ & $\begin{array}{l}9.36 \\
\text { (SD 7.02) }\end{array}$ & $\begin{array}{l}2.02 \\
(\mathrm{SD} 1.88)\end{array}$ & $\begin{array}{l}3.05 \\
(\mathrm{SD} 1.30)\end{array}$ \\
\hline E Control & $\begin{array}{l}163.95 \\
\text { (SD 49.32) }\end{array}$ & $\begin{array}{l}211.90 \\
(\mathrm{SD} 90.52)\end{array}$ & $\begin{array}{l}194.27 \\
(\mathrm{SD} 66.06)\end{array}$ & $\begin{array}{l}110.33 \\
\text { (SD 53.69) }\end{array}$ & $\begin{array}{c}109.21 \\
(\mathrm{SD} 31.45)\end{array}$ & $\begin{array}{c}12.59 \\
(\mathrm{SD} 7.23)\end{array}$ & $\begin{array}{l}13.61 \\
\text { (SD 4.52) }\end{array}$ & $\begin{array}{l}9.36 \\
\text { (SD 4.85) }\end{array}$ & $\begin{array}{l}1.16 \\
(\mathrm{SD} 0.98)\end{array}$ & $\begin{array}{l}2.52 \\
(\mathrm{SD} 0.94)\end{array}$ \\
\hline $\mathrm{p}$ value & 0.0003 & 0.0183 & 0.5316 & 0.0341 & $9.42 \times 10^{-8}$ & $4.96 \times 10^{-8}$ & 0.001097 & 0.002054 & 0.000335 & 0.000146 \\
\hline
\end{tabular}

${ }^{a} \mathrm{p}<0.005$ compared to control group.

${ }^{b} \mathrm{p}<0.05$ compared to control group.

${ }^{c} \mathrm{p}<0.0005$ compared to control group.

${ }^{d} \mathrm{p}<0.005$ between Groups A, B and Groups C, D, E.

${ }^{e} \mathrm{p}<0.05$ between Groups A, B and Groups C, D, E.

${ }^{f} \mathrm{p}<0.005$ between Groups A, B and Groups C, D, E.

${ }^{g} \mathrm{p}<0.005$ between Groups A, B and Groups C, D E.

${ }^{h} \mathrm{p}<0.005$ between Groups A, B and Groups C, D, E.

SDCP concentration, $1 \mathrm{mg} / \mathrm{ml}(\mathrm{n}=10)$.

All data were analyzed by ANOVA test. SD: standard deviation. 

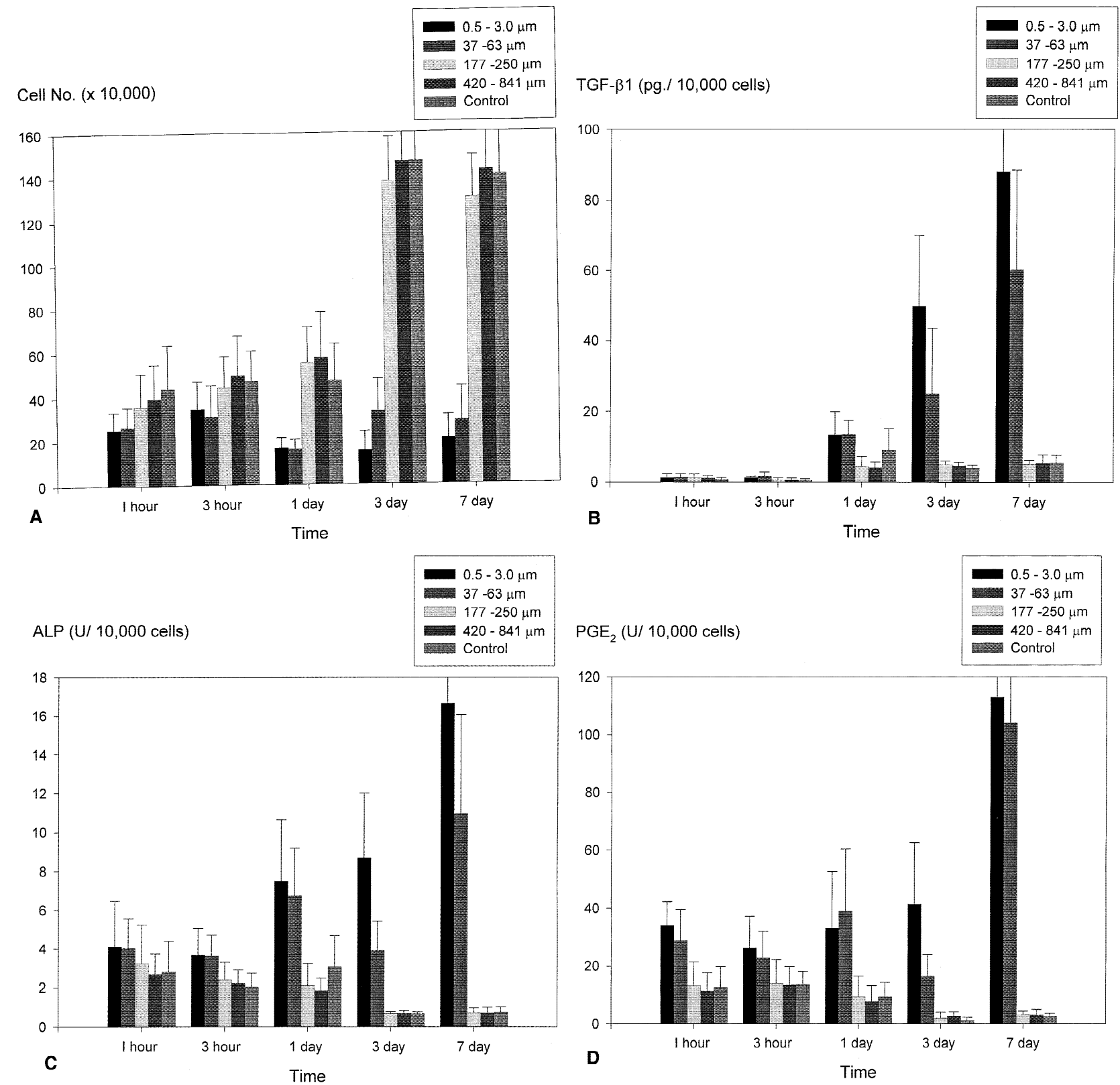

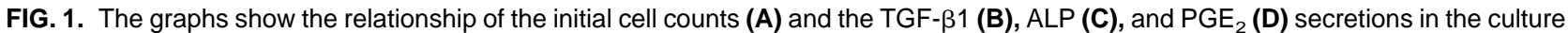
medium and the osteoblast cell counts. When osteoblasts were cultured with various sized SDCP particles, the changes in cell counts corresponded to the changes in ALP secretion while being inversely related to the changes of TGF- $\beta 1$ and PGE ${ }_{2}$ secretions in the culture medium.

cellular behavior of osteoblasts, and this effect was most significant and persisted longer in smaller particle groups (9).

$\beta$-DCP is one of the intermediate products in the biological mineralization process of bone formation (4). Sintered $\beta-\mathrm{Ca}_{2} \mathrm{P}_{2} \mathrm{O}_{7}$ with $\mathrm{Na}_{4} \mathrm{P}_{2} \mathrm{O}_{7} \cdot 10 \mathrm{H}_{2} \mathrm{O}$ addition (SDCP) has been proven to have great potential as an in vivo biodegradable bone substitute $(6,7)$. Histological examinations after implantation into the rabbit's fermur condyle showed direct deposition of new bone on the surface of the material, and the implant decreased in volume gradually $(6,7)$. We also investigated the biocompatibility of various calcium phosphates and found that HA has an inhibitory effect on the growth of osteoblasts while SDCP is more biocompatible to the osteoblasts (11). However, the effect of SDCP particles on the osteoblasts has not been well elucidated. For the quantification of the effects of specific particles on cell metabolism, osteoblast cell culture models in the presence of SDCP particles were performed.

The decrease in cell population after exposure can 
be used as a marker of cytotoxicity of the tested material (12). It has been reported that toxicity due to direct contact of particles with cells occurs only when the particle is smaller than $5 \mu \mathrm{m}$ in diameter (13). In our previous study, the adding of HA particles into osteoblast culture could significantly affect the cell counts, and a decrease in cell populations occurred in all experimental groups of various sized HA particles, the smallest sized HA having the fewest cell populations (9). In this study, the addition of larger sized SDCP particles (i.e., 177-250 $\mu \mathrm{m}$ and 420-841 $\mu \mathrm{m}$ ) into osteoblast cultures did not affect the cell population. In contrast, when osteoblasts were cultured with SDCP of smaller particle sizes (i.e., $0.5-3.0 \mu \mathrm{m}$ and $37-83 \mu \mathrm{m}$ ), the osteoblast populations were significantly less than that of the control $(\mathrm{p}<0.05)$ (Table 1). The osteoblast populations were only affected by the smaller sized SDCP particles. The SDCP particles are more bioinert than the hydroxyapatite. The mechanism of cell damage in vitro can depend on either a direct interaction between cells and particles (8) or the leaching of toxic ions to inhibit the normal cell function (12). The effects of SDCP on the synthesis and secretion of specific proteins were also evaluated in this study.

In this study, although the TGF- $\beta 1$ concentrations in the culture medium were quite similar among all experiments, the secretions of TGF- $\beta 1$ by osteoblast-like cells were significantly affected by the addition of SDCP particles (Table 2). In this study, the secretions of TGF- $\beta 1$ by osteoblast-like cells were quite similar for the experimental medium with SDCP sized 177-250 $\mu \mathrm{m}$ and 420-841 $\mu \mathrm{m}$ (Table 2). In the 7 day culture of osteoblasts, we also did not observe any increase in secretion of ALP in these groups (Table 3). This fact reflected that the larger sized SDCP particles are not only bioinert to the osteoblasts but also that our culturing condition was not optimal for the mineralization process. Similar to the changes of TGF- $\beta 1$ secretion, increases of ALP secretion by osteoblast-like cells was most significant in the group with the smallest particles (i.e., $0.5-3.0$ $\mu \mathrm{m}$ SDCP). The TGF- $\beta 1$ secretions of osteoblasts of the smaller sized SDCP $(0.5-3.0 \mu \mathrm{m}$ and $37-63 \mu \mathrm{m})$ were always significantly higher than that of the control medium after the third hour of implantation and persisted until the 7 day culture (Table 2). The secretions of ALP into the culture medium with various preparations were quite similar to those of TGF$\beta 1$; they were always significantly greater than that of the control in the culture medium with the smaller sized SDCP (i.e., 0.5-3.0 $\mu \mathrm{m}$ and 37-63 $\mu \mathrm{m}$ ) (Table 3 ).

TGF- $\beta 1$ has been shown to have stimulatory ef- fects on osteoblasts (14), and the autoinductive processes can amplify and extend the activity of TGF- $\beta 1$ (15). In the present study, the increases in the osteoblast secretion of TGF- $\beta 1$ by SDCP particles may reflect the fact that SDCP is not only bioinert but also biocompatible to the osteoblasts. The osteoblasts have traditionally been considered to be responsible for bone formation; however, the origin of osteoblasts from pluripotential stem cells present in the bone marrow stroma exhibits various stages of differentiation features (16), and ALP is expressed in the intermediate process of osteoblast differentiation $(13,17)$. As noted in the present study, the secretions of ALP into the culture medium with various preparations were quite similar to those of TGF- $\beta 1$; they were always significantly greater than that of the control in the culture medium with smaller sized SDCP (i.e., 0.5-3.0 $\mu \mathrm{m}$ and 37-63 $\mu \mathrm{m}$ ) (Table 3). This means that the addition of the smaller sized SDCP particles not only stimulated but also promoted differentiation of the osteoblasts. The growth rate of osteoblasts was determined by the death rate and their mitotic rate (16). The promotion of osteoblast differentiation by the biocompatible SDCP particles can partly explain the reason for the stationary changes in osteoblast population after the addition of smaller sized SDCP particles (Table 1).

It has been reported that smaller bone cement particles $(<20 \mu \mathrm{m})$ resulted in more inflammation than large particles $(50-350 \mu \mathrm{m})$. Large particles induced a more intense rise in the white blood cell count and in the production of $\mathrm{PGE}_{2}$ (18). In the present study, the changes of $\mathrm{PGE}_{2}$ concentration in the culture medium corresponded to the changes of cell population, TGF- $\beta 1$, and ALP secretion when osteoblasts were cultured with various sized SDCP particles. The secretions of $\mathrm{PGE}_{2}$ in the culture medium tested with smaller particle sizes (37-63 $\mu \mathrm{m}$ and $0.5-3.0 \mu \mathrm{m}$ ) were always higher than those of the control and larger SDCP particles (Table 4). The increased synthesis and release of $\mathrm{PGE}_{2}$ may act as an autocrine or paracrine factor. Also, the administration of $\mathrm{PGE}_{2}$ in various in vitro and in vivo models has led to increased bone remodeling of turnover (19), attributable to increased bone resorption $(20,21)$ or bone formation $(22,23)$, or both. In this study, the changes of $\mathrm{PGE}_{2}$ concentration in the culture medium and the secretion by osteoblast-like cells were closely related to the changes of cell population when osteoblasts were cultured with the various sized SDCP particles (Fig. 1). It is reported that the ability of various cytokines (including interleukin-1, tumor necrosis factor, and transforming growth factor- $\alpha$ ) to stimulate bone resorption is me- 
diated by increased $\mathrm{PGE}_{2}$ synthesis, and the production of these cytokines is influenced by prostaglandins (24). The inhibition effects of the smaller sized SDCP particles on the osteoblast cell cultures were possibly mediated by the increases in the synthesis and secretion of $\mathrm{PGE}_{2}$ by osteoblasts.

SCDP is one of the bioceramics that have favorable biological responses and great potential as in vivo biodegradable bone substitutes. In this study, the results of the effects of various sized SDCP particles on osteoblast-like cells manifest the possible in vivo effect of degradation products of SDCP on the adjacent ingrowing osteoblasts. They suggest that implantation of SDCP products which later break down into a fine powder form will possibly promote osteoblast-like cell differentiation and ALP secretion. In this work, only the biocompatibility of various sized SDCP particles and osteoblasts were elucidated. Further studies of the relationships of various sized SDCP particles to osteoblasts are now in progress.

Acknowledgment: The authors sincerely thank the National Health Research Institutes (ROC) for their financial support of this research.

\section{REFERENCES}

1. Stupp SI, Hanson JA, Eurell JA, Ciegler GW, Johnson A. Organoapatites: materials for artificial bone. III. Biological testing. J Biomed Mater Res 1993;27:301-11.

2. Yao CH, Sun JS, Lin FH, Liao CJ, Huang CW. Biological effects and cytotoxicity of tricalcium phosphate and formaldehyde cross-linked gelatin composite. Mater Chem Phys 1996;45:6-14.

3. Jarcho M. Calcium phosphates as ceramics as hard tissue prosthetics. Clin Orthop 1981;157:259-78.

4. Ducheyne P. Bioceramics: Material characteristics versus in vivo behavior. J Biomed Mater Res 1987;21:S219-36.

5. Kitsugi T, Yamamuro T, Nakamura T, Kotani S, Kokubo T, Takeuchi H. Four calcium phosphate ceramics as bone substitutes for non-weight-bearing. Biomaterials 1993;14:216-24.

6. Lin FH, Lin CC, Lu CM, Liu HC, Sun JS, Wang CY. Mechanical properties and histological evaluation of sintered beta- $\mathrm{Ca}_{2} \mathrm{P}_{2} \mathrm{O}_{7}$ with $\mathrm{Na}_{4} \mathrm{P}_{2} \mathrm{O}_{7} \cdot 10 \mathrm{H}_{2} \mathrm{O}$ addition. Biomaterials 1995;16:793-802.

7. Lin CC, Liao CJ, Sun JS, Liu HC, Lin FH. Prevascularized bone graft cultured in sintered porous beta- $\mathrm{Ca}_{2} \mathrm{P}_{2} \mathrm{O}_{7}$ with 5 wt $\% \mathrm{Na}_{4} \mathrm{P}_{2} \mathrm{O}_{7} \cdot 10 \mathrm{H}_{2} \mathrm{O}$ addition ceramic chamber. Biomaterials $1996 ; 17: 1133-40$.
8. Evans EJ. Cell damage in vitro following direct contact with fine particles of titanium, titanium alloy and cobalt-chromemolybdenum alloy. Biomaterials 1994;15:713-7.

9. Sun JS, Liu HC, Chang WHS, Li J, Lin FH, Tai HC. The influence of hydroxyapatite particle size on bone cell activities: An in vitro study. J Biomed Mater Res 1998;39:390-7.

10. Hupp JR, McKenna SJ. Use of porous hydroxyapatite blocks for augmentation of atrophic mandibles. J Oral Maxillofac Surg 1988;46:533-45.

11. Sun JS, Tsuang TH, Liao CJ, Liu HC, Hang YS, Lin FH. The effects of calcium phosphates particles on the growth of osteoblast. J Biomed Mater Res 1997;37:324-34.

12. Cheung HA, Haak MH. Growth of osteoblasts on porous calcium phosphate ceramic: An in vitro model for biocompatibility study. Biomaterials 1989;10:63-7.

13. Evans EJ, Clarke-Smith EMH. Studies on the mechanism of cell damage by finely ground hydroxyapatite particles in vitro. Clin Mater 1991;7:241-5.

14. Bonewald LF, Murdy MD. Role of transforming growth factor beta in bone remodeling. Clin Orthop 1990;250:261-76.

15. Sporn MB, Robert AB. Transforming growth factor-beta. Multiple actions and potential clinical applications. JAMA 1989;262:938-41.

16. Martin TJ, Ng KW. Mechanism by which cells of the osteoblast lineage control osteoblast formation and activity. $J$ Cell Biochem 1994;56:357-66.

17. Zhou H, Choong P, McCarthy R, Chou ST, Martin TJ, Ng KW. In situ hybridization to show sequential expression of osteoblast gene markers during bone formation in vivo. $J$ Bone Miner Res 1994;9:1489-99.

18. Gelb H, Schumacher HR, Cuckler J, Baker DG. In vivo inflammatory response to polymethylmethacrylate particulate debris: Effect of size, morphology, and surface area. J Orthop Res 1994;12:83-92.

19. Jee WS, Mori S, Li XJ, Chan S. Prostaglandin $E_{2}$ enhances cortical bone mass and activates intracortical bone remodeling in intact and ovariectomized female rats. Bone 1990;11: 253-66.

20. Saffar JL, Leroux P. Role of prostaglandins in bone resorption in a synchronized remodeling sequence in the rat. Bone 1988;9:141-5.

21. Collins DA, Chambers TJ. Prostaglandin $\mathrm{E}_{2}$ promotes osteoblast formation in murine hematopoietic cultures through an action on hematopoietic cells. J Bone Miner Res 1992;7: $555-61$.

22. Jee WS, Veno K, Deng YP, Woodbury DM. The effects of prostaglandin $\mathrm{E}_{2}$ in growing rats: Increased metaphyseal hard tissue and cortico-endosteal bone formation. Calcif Tissue Int 1985;37:148-57.

23. Rasmussen $\mathrm{H}$. The calcium messenger system (Part 2). N Engl J Med 1986;314:1164-70.

24. Ibbotson KJ, Twardzic DR, D'Souza SM, Hargreaves WA, Todaro GK, Mundy GR. Stimulation of bone resorption in vitro by systemic transforming growth factor-alpha. Science 1985;228:1007. 